Diabetologia 7, 107-112 (1971)

(C) by Springer-Verlag 1971

\title{
Studies in Rheology of Human Diabetes Mellitus*
}

\author{
P.-I. Brånemark, L. Latgeir, S.-E. Fagerberg and U. Breine \\ Laboratory of Experimental Biology, First Medical Service and Plastic Surgical Service, Sahlgrenska Sjukhuset, \\ University of Göteborg, Sweden
}

Received: August 10, 1970, accepted: February 5, 1971

\begin{abstract}
Summary. The rheology of blood cells studied intravascularly, and the relation between blood cells and endothelium was analyzed in vivo by high resolution, vital microscopy in four diabetic patients with varying duration of the disease. In a dipedicled, tubed skin-flap a titanium chamber with optics was implanted. A thin layer of tissue in this chamber was observed microscopically over a period of up to 4 months. Microvascular structure and function were analyzed under normal flow conditions as well as in various test situations with reduced or completely blocked flow in lipaemia and when slight local tissue trauma was added. It was found, contrary to what has hitherto been considered in the literature, that there is no aggregation of blood cells in diabetes, unless the metabolic balance is heavily upset as in acidosis. The rheology of the various types of blood cells is normal even in long-standing diabetes.
\end{abstract}

Observations rhéologiques dans le diabète sucré humain

Résumé. La rhéologie de cellules sanguines intravasculaires et les relations entre ces cellules et l'endothélium ont été analysées in vivo par la microscopie vitale de haute résolution chez quatre diabétiques ayant la maladie depuis 3 à 15 ans. Dans un fragment de peau préparé chirurgicalement en forme de tube a été implantée une chambre de titane avec un système optique. Une mince couche de tissu a été observée au microseope pendant une période allant jusqu'à quatre mois. La structure microvasculaire et la fonction ont été analysées sous des conditions de eirculation normale et pendant différentes situations de test avec blocage partiel ou total de la circulation, pendant une lipémie et après des traumatismes locaux légers. En contradiction avec les opinions publiées dans la littérature, il n'y a pas d'aggrégation de cellules sanguines chez des diabétiques, sauf au cours d'une perturbation métabolique prononcée comme dans l'acidose. La rhéologie des différents types de cellules sanguines est normale même dans le diabète de longue durée. On donne une explication du concept admis jusqu'à maintenant, de l'aggrégation des cellules sanguines dans le diabète.

Rheologische Untersuchungen beim menschlichen Diabetes mellitus

Zusammenfassung. Die Rheologie intravasculär untersuchter Blutzellen und die Beziehungen zwischen Blutzellen und Endothelium wurden vitalmikroskopisch unter hoher Auflösung bei vier Diabetikern mit unterschiedlicher Krankheitsdauer in vivo analysiert. In einen zweizipfligen, röhrenförmigen Hautlappen wurde eine Titanium-Kammer mit Optik implantiert. In dieser Kammer wurde eine dünne Gewebsschicht bis zu vier Monaten mikroskopisch untersucht. Die mikrovasculäre Struktur und ihre Funktion wurden unter normalen Strömungsverhältnissen und während verschiedener Test-Situationen mit partieller oder totaler Strömungsunterbrechung bei Lipämie und nach leichten lokalen Gewebstraumen analysiert. Im Gegensatz zu bisher in der Literatur vertretenen Ansichten fand sich dabei nur dann eine Aggregation von Blutzellen bei Diabetikern, wenn es unter einer Azidose zu einer schweren Stoffwechselstörung gekommen war. Auch bei Langzeitdiabetes waren die Strömungseigenschaften der verschiedenen Blutzellarten normal.

Key-words: Diabetes mellitus, microcirculation, rheology, vital microscopy, aggregation of blood cells.
Published investigations into the rheology of blood and microvascular pathophysiology in human diabetes have been based on examinations of blood in vitro or on in vivo-analysis of blood flow in conjunctival vessels using low resolution optical systems. (Camerini-Davalos et al., 1963; Ditzel et al., 1967, 1968; Rees et al., 1964). But the circulatory problem in diabetes is mainly confined to the nutritive segment of the circulatory system, i.e. capillaries and small venules. Hence this is the level where intravascular rheology in this disease requires analysis. Obviously, too, conclusions about the rheology of blood in microvascular compartments, can only be based on inferences from

* Supported by grants from Swedish Diabetic Association, Swedish Medical Research Council and Swedish National Association against Heart and Chest Diseases. physical characteristics of blood withdrawn from a major vessel and transferred to a system in vitro, and may therefore not in all details represent the situation in vivo.

Intravascular phenomena in diabetic microangiopathy thus occur at the cellular level. The morphology and dynamics of the various types of blood cells, of plasma constituents and of endothelium and periendothelium must be considered, in order to provide an accurate background for interpretation of the microvascular pathophysiology in this disease. It would seem. that methods used hitherto do not in all respects meet these requirements.

The aim of the present study was to delineate intravascular anatomy and physiology in the microcirculation of diabetics'. 


\section{Material}

In this study 4 volunteers with diabetes mellitus were subjected to investigation: two male students 25 years of age with a duration of the disease of 3 and 5 years, respectively. The disease was well controlled, and there was neither manifest microangiopathy nor other structural or functional complications related to the disease. One female student, 25 years old, with diabetes mellitus of 5 years' duration had no signs of vascular complications. The fourth subject, a female 20 years of age, had diabetes mellitus for 15 years and showed manifestations of fairly severe complications: retinopathy with microaneurysms and haemorrhages, and nephropathy with constant proteinuria without signs of infection. During the period of study this patient developed several episodes of mild acidosis and ketosis with serum carbon dioxide of 40 to 50 volumes per $100 \mathrm{ml}$.

\section{Methods}

The analysis of the intravascular rheology of blood was performed with the aid of a titanium chamber technique for high resolution analysis of microcirculation in man (Brånemark 1964, 1971), enabling examination in vivo at the resolution level of the light microscope.

Four months prior to the microcirculatory investigation, a dipedicled, tubed skin-flap was surgically prepared on the inside of the left upper arm of each volunteer. After a healing period of 3 months, a titanium chamber containing an optical system was installed in the tube (Fig. 1). This chamber consists of a titanium framework, which is secured to the skin tube and contains a light-conducting quartz rod and a cover slip. There is a distance of $50 \mu$ between the upper surface of the quartz rod and the lower surface of the cover slip. This space becomes vascularized by sprouting vessels, and invaded by granulation tissue. The tissue matures over a period of $3-4$ weeks, and then represents ordinary subcutaneous connective tissue with a microvascular topography and physiology apparently equivalent to the original tissue. In normal subjects microvascular flow patterns, vasomotion and microvascular reactions to injury are similar to those in original connective tissue.

The first observations of the microvascular system in the chamber space were made $4-5$ weeks after installation of the chamber in the tube, and were then continued over a period of 3-4 months.

The analysis was performed in a specially designed, high resolution, intravital microscope (Brånemark 1971). The intravascular anatomy and pathophysiology were recorded photomicrographically. Numerical analysis of microvascular dynamics was accomplished by transferring the optical image to a closed-circuit television system with video tape recorder. The infor- mation on the tape was then subjected to various types of linear and dynamic analysis.

After the investigation was completed, the skin tube with chamber was removed, and the skin flaps repositioned to reconstruct the original surface anatomy of the arm.

In order to provide a broad basis for evaluation of the microcirculation, various test situations were created:

1. Extensive examinations were made under normal flow conditions.
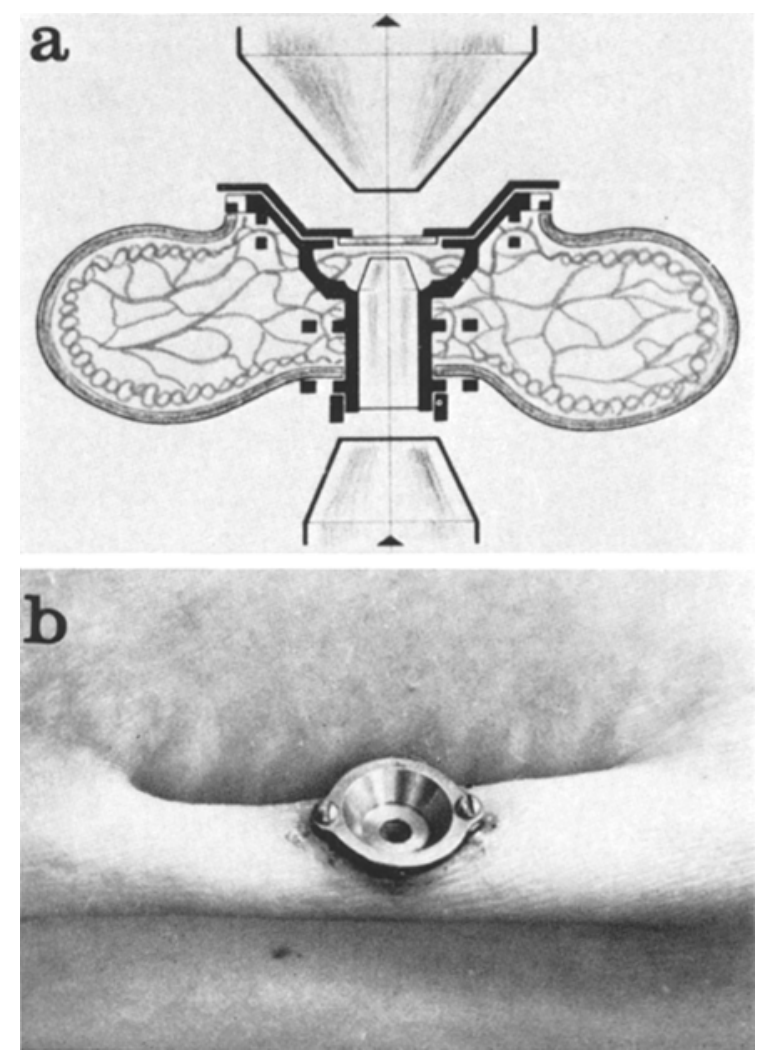

Fig. 1 a. Cross-section of dipedicled, tubed skin-flap with titanium chamber in situ

b. Dipedicled, tubed skin-flap with chamber in oblique view

2. The position of the chamber in a dipedicled, tubed skin-flap provides excellent opportunities for delicate control of circulatory flow rates in the chamber space by compression of the ends of the skin tube. Observations were made at varying degrees of reduced flow. 3. In order to provide an opportunity to visualize plasma rheology and to provide an indication of the suspension stability of plasma, observations were also made after high intake of fat in the form of milk cream. 30-40 min after fat intake, chylomicrons could readily by observed in the microvessels.

4. In order further to stress the test situation and to provide information on the reactions of the micro- 
vessels and their constituents to tissue injury, the circulation in the skin tube was completely occluded for varying periods from $5 \mathrm{~min}$ to $3 \mathrm{~h}$, resulting in complete circulatory standstill under direct visual control.

5. In addition to the occlusion of the circulation, slight local trauma was in some experiments added in the form of mechanical stretehing of the tissue and exposure of the chamber tissue to near ultraviolet radiation. the red cells, and their plasticity was maintained even after long periods of circulatory standstill. (Fig. 2.)

The erythrocytes exhibited normal plasticity when passing narrow vascular segments (Fig. 4.). They showed no signs of adherence to each other or to the endothelium. Diapedesis of red cells was noted of the same kind and degree as in healthy volunteers. When the red cells had been trapped in a microvaseular segment for up to $3 \mathrm{~h}$, the content of the vessel became "homogenized" (Brånemark, 1971). At release of flow,
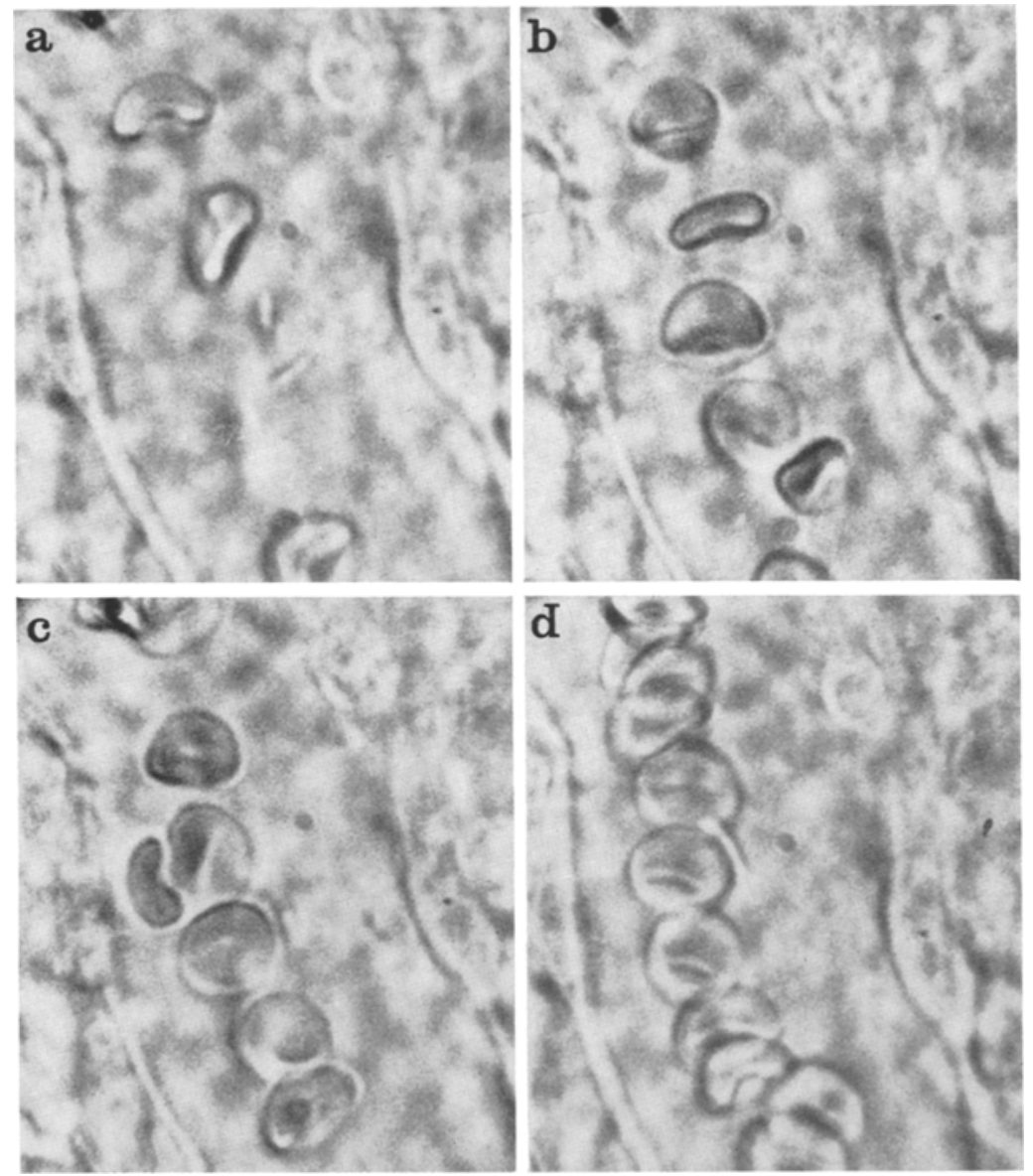

Fig. $2 \mathrm{a}-\mathrm{d}$. Anatomy of red cells and platelets in a venule at varying flow velocities in a diabetic patient of 5 years duration with no clinical signs of diabetic microangiopathy. There is a suecessive increase in flow velocity from a) to d). The red cells did not show any signs of adhesion to each other or to the endothelium. The same applies to the platelets. In a) there are two platelets in the plasma space between the erythrocytes. Enlargement from $16 \mathrm{~mm}$ Kodachrome cinerecording. $\times 1250$

\section{Results}

The observations in the various test situations on the 3 volunteers without manifest signs of microangiopathy showed, in all essential details, normal microcirculatory conditions compared. with observations on healthy volunteers at the same age (Brannemark, 1971).

The erythrocytes were biconcave. No morphologic abnormalities were observed. The dise shape was rapidly restored, even after extreme deformation of however, this mass of red cells immediately broke up into separate red cells with normal morphology and rheology. At low flow rates rouleaux formations occured as in healthy volunteers (Brånemark, 1971), but the red cells in the rouleaux did not adhere to each other with recognizably greater forces than under normal conditions in healthy volunteers. The rouleaux broke up readily with increase of flow without any signs of tendencies to block the microvessels. The rouleaux formations did not adhere to the endothe- 
lium, platelets did not adhere to the rouleaux, nor were there any signs of adhesion between the granulocytes and the rouleaux. During periods of lipaemia with large amounts of chylomicrons in plasma, erythrocyte rheology was normal. Even when the flow was completely blocked and the red cells were trapped together with chylomicrons in a microvessel for up to $3 \mathrm{~h}$, no signs of increased adhesion were noted between red. cells or between red cells and endothelium, nor was there any sign of adhesion of chylomicrons to the red. cell surface.

Granulocytes are normally more rigid than erythrocytes (Brånemark, 1970, 1971). Owing to their internal visco-elastic properties granulocytes constitute a temporary hindrance to blood flow in the microcirculation. However, provided perfusion pressure is maintained (Branemark, 1969), the granulocyte as a rule adapts its shape to fit the anatomy of the vessel and is then released and circulation is restored. In the three volunteers without microangiopathy, granulocytes of different kinds displayed this adaptability. In no case did the granulocytes block flow permanently. The remodelling of the cells when trapped appeared to occur in the same manner and to require the same period of time as in healthy volunteers. However, further investigations concerning remodelling time are required to settle definitely the question of granulocyte rigidity in vivo in diabetes. Equally important and required is a numerical evaluation of the resistance to flow produced by the granulocytes (Branemark, 1969).

Platelets were of normal disc shape, 3-4, eventually $5-6 \mu$ in diameter, and quite rigid. Adhesion of platelets to each other, to other blood cells or to the endothelium was not observed in any of these three volunteers in the various test situations (Fig, 2a). Even in long-standing complete blockage of flow the platelets maintained their integrity. No platelet aggregates or microthrombi were formed.

Plasma rheology was visualized by the movements of the blood cells, particularly platelets. In the experiments with induced lipaemia, the chylomicrons provided excellent visualization of plasma movements, especially under low-flow conditions. When in low-flow states plasma skimming occurred, rou leaux formations appeared. Platelets and chylomicrons disclosed that plasma movements were of the same kind as in healthy volunteers. The marginal plasma zone in capillaries and venules showed the same flow patterns as in healthy volunteers.

The endothelial wall of these newly formed vessels did not show any abnormalities in any of the test situations. There were no recognizable signs of increased rigidity as visualized by the behaviour of erythrocytes and granulocytes, when passing narrow vascular segments. At blockage of flow, red cells diapedesis occurred, but to the same extent and of the same kind and pattern as in healthy volunteers under similar conditions. There were no signs of adhesion between the endothelium, blood cells or plasma constituents, e.g. chylomicrons. The integrity of the endothelium persisted even after $3 \mathrm{~h}$ of complete circulatory standstill, at least as evidenced by diapedesis and by the fact that endothelium-adhering microthrombi or endothelium-adhering blood cells were not observed.

When flow was restored after such a long period of circulatory blockage, no signs of endothelial dysfunction were noted in the period immediately after
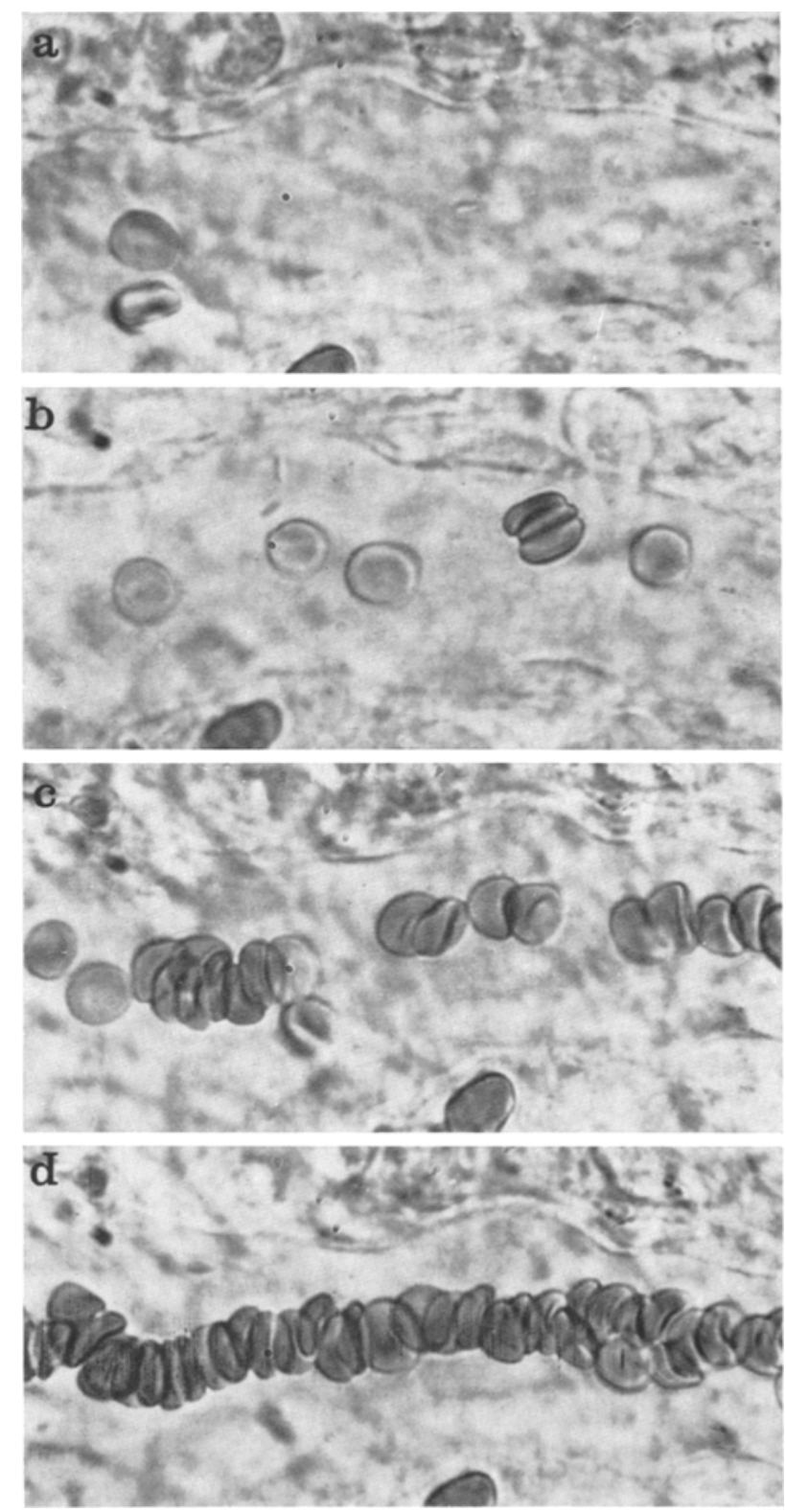

Fig. $3 a-d$. Anatomy of red cells and platelets in a venule at varying flow velocities in a diabetic patient with clinical signs of diabetie microangiopathy of 15 years duration (Case 4). In a) and b) separate red cells and platelets are discernible in the plasma space. There were no signs of adhesion between red cells and endothelium or between platelets and endothelium. Photomicrograms recorded on Gevaert Scientia 45C62. × 1400 
release of flow. The analysis was continued for $3-4 \mathrm{~h}$ after release of flow and the microcirculation was examined during the following days. In no case, however, was there any sign of microvascular abnormality.

In the case of the fourth volunteer, the 20 year old girl with diabetes of 15 years duration, the same test situations were applied as for the three other volunteers. The structure and function of the microvascular system in the chamber space were analysed with respect to all parameters described above concerning blood cells, plasma and endothelium. Repeated observations in vivo of the structure of the wall of the microvessels in this case, as also in the other 3 cases, did not reveal any signs of structural abnormalities in the endothelium itself or in the periendothelium of the newly formed tissue in the chamber (Fig. 3, 4).

\section{Comments and Conclusion}

The prevailing concept as it appears in the literature is that in diabetes mellitus disturbances occur in the rheology of blood, the predominating features being aggregation of erythrocytes and increased viscosity (Ditzel, 1967, 1968; Rees et al., 1964; Skovborg et al., 1966). Our investigation has shown that in four cases of diabetes with a duration of $3-15$ years aggregation of erythrocytes could not be observed, not even when slow flow or complete standstill of flow was produced or when slight local tissue trauma was added. Only in one diabetic patient in a state of metabolic acidosis did platelet adhesion occur. When the metabolic balance was maintained, no signs of intravascular rheologic aberrations were noted. The suspension stability
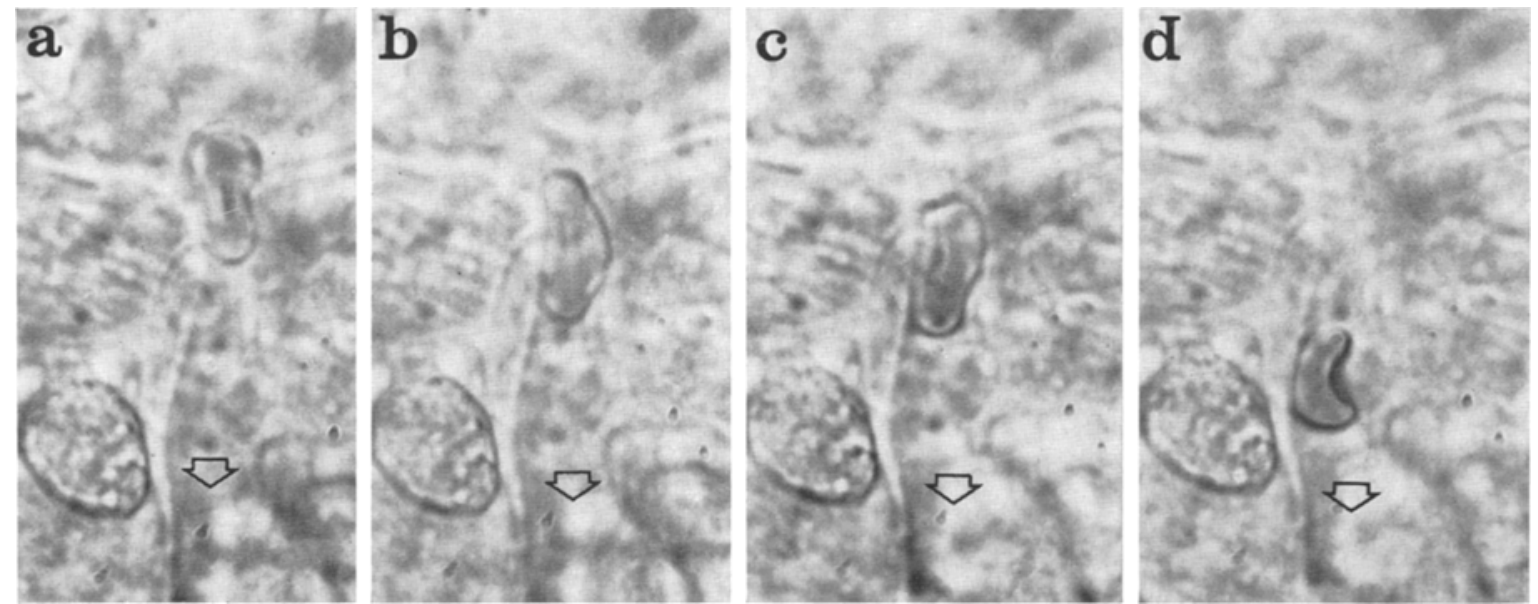

Fig. 4a-d. Consecutive photomicrograms of an erythrocyte showing deformation or the red cell passing a narrow capillary with a diameter of $2.5 \mu$ at the branching from the precapillary vessel. The normal plasticity of the red cell in this case of diabetes of 15 years duration (Case 4) is clearly evident. Photomicrograms recorded on Gevaert Scientia 45 C $62 . \times 1000$

In this case of advanced microangiopathy it was found that the erythrocytes, granulocytes, platelets, plasma and newly formed endothelium showed similar morphologic and dynamic features as in the three other volunteers. Thus, there were no signs of erythrocyte adherence or aggregation or any other rheologic aberration in the various test situations (Fig. 3). Only in one respect did this volunteer deviate in microvascular rheology compared with the other three volunteers. During the period of examination this patient had episodes of mild acidosis, which were rapidly corrected and controlled. However, when slow flow or complete standstill of circulation was instituted during the acidotic period, it was observed that platelets did adhere to each other soon after reduction in circulatory flow rates. These aggregates were loose, did not adhere to the endothelium and broke up again when the circulation was released. No firm aggregates were observed.

In every other respect this patient showed the same rheologic characteristics in the microvascular system examined as the other volunteers (Fig. 4). of plasma as visualized by experimentelly produced lipaemia appeared normal. The endothelium displayed no abnormalities.

Thus, nutritive flow of blood in microvascular compartments in diabetes shows the same structural and functional characteristios as in healthy volunteers under similar test situations. The integrity of the various types of blood cells, plasma and the newly formed endothelium appears to be of the same kind and magnitude as in healthy subjects.

In this study only 4 patients were observed. There is, however, no reason to believe that these randomly selected patients should in any way differ distinctly from other diabetics in their microvascular anatomy and physiology. It is very unlikely that the reason or the explanation for the discrepancy in our interpretation of rheology of blood cells, studied intravascularly, in diabeties and the hitherto prevailing concepts should be based on peculiarities in our volunteers' microvascular compartments. It is much more likely that the explanation is to be found in discrepancies be- 
tween previous investigators' and our methods of analysis. In all investigations hitherto on diabetes in man with relation to intravascular rheology, optical systems have been mostly focused on the conjunctival vessels, which do not according to physical principles allow resolution, discrimination or identification of the cellular interphase. Only with high resolution systems is it possible to observe this critical intercellular zone. Furthermore, the rheologic characteristics of the separate blood cells must be analyzed at the level of cellular details, if the question of cellular rheology is to be settled.

Therefore, on the basis of our study, we conclude that aggregation of blood cells is not a common phenomenon in diabetes mellitus in man. On the contrary, the corpuscles of blood exhibit a distinct integrity which they maintain even in low flow situations and in periods of complete standstill of the circulation.

When we observed the microvascular compartments at low microscopic resolution levels at the same level of identification used by others at slow flow conditions, plasma skimming phenomena occurred and sometimes rouleaux were formed as described in detail above. At that level of resolution we were not able to decide however, whether or not the cells were adhering to each other or whether the adhesion of the cells to each other in the rouleaux was tighter than normal. Therefore, it is our opinion that the aggregation of erythrocytes attributed to diabetic microangiopathy and even to the prediabetic stage is in fact the optical sign of low flow state, which should not be confused with intravascular aggregation of blood cells. Even considering the fact that our studies were performed on newly formed microvessels one to three months old, we still deem it justified to formulate the preceding primarily tentative deductions, since our ob- servations and conclusions concern the interrelation between blood cells within endothelial tubes in situ in vivo and not the relation of blood cells to the endothelial cells.

Acknowledgement: Research assistance by Miss M. Dunér and Miss Y. Winsnes is gratefully acknowledged.

\section{References}

Brånemark, P.-I., Aspegren, K., Breine, U.: Microcirculatory studies in man by high resolution vital microscopy. Angiology 15, 329-332 (1964).

- Pathophysiology of microcirculation in shock in relation to metabolic changes. (proc. from symposium on shock, Freiburg 1969) (in press).

- Intravascular anatomy of blood cells in man. Basel: Karger 1971.

Camerini-Davalos, R.A., Caulfield, J.B., Rees, S.B., Lozano-Castaneda, O., Naldjian, S., Marble, A.: Preliminary observations on subjects with prediabetes. Diabetes 12, 508-518 (1963).

Ditzel, J.: Haemorrheological factors in the development of diabetic microangiopathy. Brit. J. Ophthal. 51, $793-803$ (1967).

- The in vivo reactions of the small blood vessels to dia betes mellitus. Acta med. scand. Suppl. 473 (1967).

- Functional microangiopathy in diabetes mellitus. Dia. betes 17, 388-397 (1968).

Rees, S.B., Camerini-Davalos, R.A., Caulfield, J.B. Lozano-Castaneda, O., Cervantes-Amezcus, A., Taton, J., Pometta, D., Krauthammer, J.P., Marble A.: Pathophysiology of microangiopathy in diabetes mellitus. CIBA Found. Coll. Fndocrin. 15, 315-344 (1964).

Skovborg, F., Nielsen, A., Schlichtkrull, J., Ditzel, J.: Blood-viscosity in diabetic patients. Lancet 1966 I, $129-131$.

\author{
P.-I. Brånemark M.D. \\ University of Göteborg \\ Faculty of Medicine \\ Dept. of Anatomy \\ Lab. exp. Biology \\ S-40033 Göteborg 33, Sweden
}

